\title{
The price of safety: costs for mitigating and coping with Alpine hazards
}

\author{
C. Pfurtscheller ${ }^{1}$ and A. H. Thieken ${ }^{2}$ \\ ${ }^{1}$ Institute for Interdisciplinary Mountain Research, Austrian Academy of Sciences, Innsbruck, Austria \\ ${ }^{2}$ Institute of Earth and Environmental Sciences, University of Potsdam, Potsdam, Germany \\ Correspondence to: C. Pfurtscheller (clemens.pfurtscheller@oeaw.ac.at)
}

Received: 1 August 2012 - Published in Nat. Hazards Earth Syst. Sci. Discuss.: Revised: 23 July 2013 - Accepted: 28 July 2013 - Published: 22 October 2013

\begin{abstract}
Due to limited public budgets and the need to economize, the analysis of costs of hazard mitigation and emergency management of natural hazards becomes increasingly important for public natural hazard and risk management. In recent years there has been a growing body of literature on the estimation of losses which supported to help to determine benefits of measures in terms of prevented losses. On the contrary, the costs of mitigation are hardly addressed. This paper thus aims to shed some light on expenses for mitigation and emergency services. For this, we analysed the annual costs of mitigation efforts in four regions/countries of the Alpine Arc: Bavaria (Germany), Tyrol (Austria), South Tyrol (Italy) and Switzerland. On the basis of PPP values (purchasing power parities), annual expenses on public safety ranged from EUR 44 per capita in the Free State of Bavaria to EUR 216 in the Autonomous Province of South Tyrol. To analyse the (variable) costs for emergency services in case of an event, we used detailed data from the 2005 floods in the Federal State of Tyrol (Austria) as well as aggregated data from the 2002 floods in Germany. The analysis revealed that multi-hazards, the occurrence and intermixture of different natural hazard processes, contribute to increasing emergency costs. Based on these findings, research gaps and recommendations for costing Alpine natural hazards are discussed.
\end{abstract}

\section{Introduction}

Every year, hazards in Alpine environments, such as floods, debris flows, avalanches and landslides, cause significant losses to the residential, commercial, industrial, agricultural and public sector. The CRED EM-DAT database counts 150 catastrophic events with an estimated EUR 38 billion direct losses in Austria, France, Germany, Italy, Slovenia, and Switzerland from 1950 to 2009. However, only a part of these losses, which cannot be separated reliably, was triggered by Alpine hazards. Based on a database of floods, debris flows, landslides and rockfalls in Switzerland, the total direct losses were estimated to EUR 8 billion from 1972 to 2007 (Hilker et al., 2009). In Italy, an analysis of data on floods and landslides from 1279 to 2002 showed 2682 events with more than 50000 fatalities without counting the total losses in monetary values (Guzzetti et al., 2005). In Austria, 4894 flood and debris flows events, as well as intermixture processes, were counted from 1972 to 2004 with a total direct loss of EUR 965 million including clean-up costs (Oberndorfer et al., 2007). These figures clearly reveal the need for risk reduction and for an assessment of the costs involved. According to Zeckhauser (1996) the costs of natural hazards are defined as the sum of losses from an event plus the costs of actions to reduce them.

In recent years, there has been a growing body of literature on the estimation of losses due to natural hazards (see e.g. Meyer et al., 2013 for a review of methods), but there is only limited information on the costs of public safety, although this information is needed for assessing the economic efficiency of risk reduction strategies. Insofar, expenses for mitigation could be compared with the implemented risk reduction strategies and levels of protection (Benson and Clay, 2004). Moreover, the economic efficiency of these expenditures on natural hazard management is of high importance to identify the most suitable mitigation strategy (Raschky and Weck-Hannemann, 2008; Altay et al., 2013). In that 
sense, economic integral risk management aims to protect population and physical assets by reasonable means and efficiency of resources. Relief spending is often much more cost-intensive than prevention (The World Bank, 2010), thus it makes sense to balance different systems of prevention and risk transfer, and their costs against the losses. Hence, a weighting of the expenses and the effectiveness of any mitigation measure (and not only the preventive effects of the measure) can be carried out to identify the most cost-efficient mitigation strategy. For example, alternative measures like warning in combination with evacuations or relocations of households could be more economically advantageous than technical measures in a certain catchment area.

Since risk management is usually a public task and safety from natural hazards is a public, non-tradeable good (Ganderton, 2005), the efficient allocation of public resources for mitigation is needed to support local and regional mitigation policies carried out by public administrations. To improve the economic efficiency of natural hazard mitigation, all costs triggered by a single hazard event have to be analysed to arrive at estimates for an ex-ante assessment, e.g. within a cost-benefit framework for mitigation measures or similar methods for decision support (Benson and Clay, 2004). For the European Alps several case studies and analyses have been carried out focusing on cost-benefit or costeffective-approaches of local protection measures. Fuchs and McAlpin (2005) computed the net benefits of avalanche protection in Davos, Switzerland, based on the costs spent for mitigation and the losses prevented. They assessed building values and loss of life using a human capital approach. Evaluating risk reduction scenarios using different combinations of technical and alternative measures (evacuation, land use planning), again in Davos, the scenario of snow fences and land use provides the highest net present values and thus has to be considered as the economically most efficient risk reduction measure (Fuchs et al., 2007). Other research focused on the economic valuation of ecosystems services of forests and avalanche protection. While Grêt-Regamey et al. (2008) carried this out within a framework of evaluating ecosystem services that also addresses scenic beauty, carbon sequestration and the habitat of a certain plant for new expansion areas of Davos, Switzerland, Olschewski et al. (2012) and Olschewski (2013) spotlight the economic value of protective forests using a willingness-to-pay framework. Moreover, they analysed the costs of technical measures compared to the results of the choice experiments. Such studies provide meaningful results for a local assessment of mitigation costs. Nevertheless, on regional or national scales, estimates of such costs are missing, except for a notable study from Switzerland by Wegmann et al. (2007). In Austria, Oberndorfer et al. (2007) assessed the expenses for technical mitigation measures against torrents with EUR 1.84 billion from 1972 to 2004. Altogether, no appropriate approaches have been developed to comprehensively analyse all costs occurring before, during, and after events. Although data on di- rect losses becomes more and more available, costs for hazard mitigation are usually neither collected nor analysed on aggregated levels systematically. Hence, what is basically needed is a reporting on such public spending on mitigation and other risk reduction measures (Benson and Clay, 2004).

In this paper, we argue that the costs of public safety mainly consist of two categories: (1) fixed costs for mitigation arising before a disaster occurs and (2) variable emergency costs that only occur in case a hazardous event occurs. The main aims of the paper are (1) to compare the (fixed) costs of mitigation in different Alpine regions and (2) to determine the share of (variable) costs for emergency services during the flood in 2002 in Germany and in 2005 in the Federal State of Tyrol (Austria) in relation to direct losses and (3) to determine factors that drive emergency costs.

The paper is structured as follows. It first introduces the economic cost assessment of natural hazards in Alpine environments (Sect. 2). Section three analyses the annual costs for mitigation and public safety in different regions within the Alpine Arc (Switzerland, the Free State of Bavaria Germany, the Federal State of Tyrol - Austria, and the Autonomous Province of South Tyrol - Italy). Section four focuses on costs for emergency management. First, costs for emergency management are related to direct costs and secondly, estimates of the costs occurred during and after the 2005 flood event in the Federal State of Tyrol (Austria) based on questionnaire data of the local fire departments are used to derive factors that influence emergency costs. Section five concludes and gives recommendations for public and private hazard and risk management.

\section{Economic costing of Alpine hazards - principles and cost categories}

In the case of natural hazards measuring adverse economic effects is mostly equated with estimating the direct loss on a national scale after an event has occurred, based on available data (e.g. EM-DAT). From an economic point of view, post-disaster costs are all negative monetary consequences triggered by a natural hazard event, whereas pre-disaster costs comprise all costs of diverse mitigation (or prevention) strategies necessary for achieving a certain generally accepted safety level. Not much research has been undertaken to systematize these cost categories (or effects) of natural hazards.

A holistic categorization of mitigation is presented by Bouwer et al. (2011). They suggest distinguishing: (1) management plans, land-use planning and climate adaptation, (2) hazard modification, (3) infrastructure, (4) mitigation measures, (5) communication, (6) monitoring and early warning systems, (7) emergency response and evacuation, (8) financial incentives, and finally (9) risk transfer. Skoufias (2003) highlights coping strategies at the household und government level and primarily distinguishes between 
coping and (ex-ante) risk reduction. He also lists actions and interventions that could be undertaken at the household and public level to minimize adverse effects after an event occurs.

A literature study by the World Bank (2010) identifies the following categories of pre-disaster expenses (p. 106):

- expenditures on identifying risks (risk analysis and mapping),

- risk reduction (in the sense of technical mitigation),

- risk transfer (insurance), and

- disaster preparedness (early warning systems, training to enhance risk awareness).

Post-disaster spending includes:

- emergency responses (search and rescue, relief, etc.),

- rehabilitation, and

- reconstruction.

The two categories are mainly used in this paper.

Generally, there is no systematic collection of data on the costs of mitigation (or prevention, used synonymously). Such cost figures are highly dependent on the institutional, geographical and hazard-specific settings (Benson and Clay, 2004). To assess the costs for mitigation and emergency management of natural hazard events, a formal systematization has to be carried out. We suggest linking cost categories to phases of the generally accepted integral risk management cycle. The risk (or disaster) management cycle was already introduced by Carter in 1991. Basic phases of response (during the event), recovery (shortly after the event) as well as mitigation, prevention and preparedness were distinguished. Carter (1991) already emphasised the need for a post-disaster review in order to reveal deficiencies in disaster management. This was further developed e.g. by Kienholz et al. (2004), who introduced a phase of systematic risk analysis before prevention planning starts. The risk management cycle has been widely used by international and national organisations and various versions have been published (Thieken et al., 2007). In the Alpine space, for example, the concept was implemented into federal activities in Switzerland by PLANAT (2004).

In this paper, the cycle is used to relate disaster-related costs as identified by the World Bank (2010) to the different stages of the risk management cycle as shown in Table 1. Following a concept of business administration, it is further distinguished whether the natural hazard events cause fixed and variable costs in the different categories.

Apart from the systematization of the different cost categories, the question Who is paying for what needs further explanation. As an example, Table 2 identifies the most relevant public and private institutions in the introduced cost framework within natural hazard and risk management in
Austria, which pay for the different categories. In sum, there are a high number of cost benefactors or payers in the case of natural hazards, even though they are also responsible for man-made and other natural hazards, dependent on the legal framework.

The price of safety always depends heavily on the societal and political decisions on the level(s) of protection. Societal needs for protection and directly connected resources for natural hazard mitigation are up against scarce public budgets. However, a holistic costing of all categories would be highly important for ensuring monetary efficiency in natural hazard and risk management. This means identifying the most suitable level of public resource spending for risk reduction and coping with adverse hazard impacts (Benson and Clay, 2004). Most of the categories introduced to in Table 1 are not comprehensively and inter-institutionally assessed in economic terms by public administrations. Each institution counts costs in these categories separately (The World Bank, 2010) und thus, an assessment of the total costs is difficult to be carried out. In addition, costs of disasters include hidden costs and benefits which are difficult to identify and quantify (Downton and Pielke, 2005). The lack of reliable, consistent and comparable (cost) data is seen as a major obstacle for risk analyses and effective and long-term loss prevention (e.g. Changnon, 2003; Downton and Pielke, 2005).

Moreover, cost assessments for some categories, e.g. output losses or co-costs and co-benefits, are totally missing, apart from single case studies, as summarized by Pfurtscheller et al. (2011) for Alpine regions. Usually cost-benefit-analysis (CBA) for future mitigation measures against Alpine natural hazards is carried out by public authorities in all Alpine countries, using different approaches and estimating different damage categories (Pfurtscheller and Thieken, 2012). Additionally, research how to improve such methods has been performed. For the Alpine Space, CBA for avalanche protection using different scenarios was presented for instance by Fuchs and McAlpin (2005) and Fuchs et al. (2007). These studies also evaluated costs for technical and non-technical measures. Until now such analyses have only been applied to local prevention projects, except for a comprehensive study carried out in Switzerland analysing the total public expenses in risk and disaster management on the national level (Wegmann et al., 2007).

Data for such assessments cannot be gathered easily due to a lack of inter-ministerial departments responsible for hazard and risk management and because multiple public bodies are involved at national, regional, and local levels. What is needed are disaggregated data, which must be collected starting on the smallest scale as all public actors involved pay for natural hazard mitigation and preparedness. Moreover, in Austria annual budgets for risk management for natural hazards comprising all administrative levels are missing, also due to the absent legal basis accounting for risk reduction. There are no national or regional-scale approaches available which estimate the costs (and damages) of natural 
Table 1. Overview of cost types occurring at different stages of natural hazards; based on concepts of Kienholz et al. (2004) and The World Bank (2010).

\begin{tabular}{|c|c|c|c|c|}
\hline & \multicolumn{2}{|c|}{ post-disaster spending/costs of coping and reconstruction } & \multicolumn{2}{|c|}{ pre-disaster spending/costs of mitigation } \\
\hline $\begin{array}{l}\text { stage of risk } \\
\text { cycle }\end{array}$ & $\begin{array}{l}\text { emergency management and } \\
\text { response, (intervention) }\end{array}$ & $\begin{array}{l}\text { reconstruction and recovery, } \\
\text { (recondition and reconstruc- } \\
\text { tion) }\end{array}$ & $\begin{array}{l}\text { risk analysis (including } \\
\text { planning) }\end{array}$ & $\begin{array}{l}\text { prevention (mitigation) and } \\
\text { preparedness }\end{array}$ \\
\hline $\begin{array}{l}\text { main cost } \\
\text { category }\end{array}$ & variable operational costs & variable damage and losses & $\begin{array}{l}\text { planning costs and decision } \\
\text { support - fixed costs }\end{array}$ & $\begin{array}{l}\text { costs of risk reduction - } \\
\text { fixed costs }\end{array}$ \\
\hline \multirow[t]{5}{*}{ examples } & $\begin{array}{l}\text { emergency response and } \\
\text { management, alert, uphold- } \\
\text { ing communication }\end{array}$ & $\begin{array}{l}\text { definitive repair and recon- } \\
\text { struction of direct losses (asset } \\
\text { losses) }\end{array}$ & $\begin{array}{l}\text { estimate of costs and bene- } \\
\text { fits of risk reduction options }\end{array}$ & $\begin{array}{l}\text { annual costs for emergency } \\
\text { infrastructure including } \\
\text { operation and training (Red } \\
\text { Cross, fire departments, } \\
\text { etc.), early costs of addi- } \\
\text { tional forces (army, police, } \\
\text { volunteers) }\end{array}$ \\
\hline & $\begin{array}{l}\text { search and rescue, evacua- } \\
\text { tion, health care, providing } \\
\text { shelter, food and water }\end{array}$ & $\begin{array}{l}\text { losses due to business inter- } \\
\text { ruption }\end{array}$ & $\begin{array}{l}\text { concept and design of risk } \\
\text { reduction measures }\end{array}$ & $\begin{array}{l}\text { investment and construction } \\
\text { costs of technical mitiga- } \\
\text { tion and related infrastruc- } \\
\text { ture, costs for operation, } \\
\text { use, maintenance and dis- } \\
\text { posal }\end{array}$ \\
\hline & $\begin{array}{l}\text { clean-up, repair of critical } \\
\text { infrastructure, provisional } \\
\text { repair }\end{array}$ & $\begin{array}{l}\text { (long-term) output losses (in- } \\
\text { direct losses) }\end{array}$ & $\begin{array}{l}\text { decision support for choos- } \\
\text { ing the best risk reduction } \\
\text { option by using e.g. CBA, } \\
\text { CEA, MCA }\end{array}$ & $\begin{array}{l}\text { early warning, monitoring, } \\
\text { awareness building, com- } \\
\text { munication }\end{array}$ \\
\hline & $\begin{array}{l}\text { maintaining transportation } \\
\text { and supply, temporary } \\
\text { protection, safe-guarding, } \\
\text { water-pumping }\end{array}$ & $\begin{array}{l}\text { losses of non-market goods } \\
\text { (intangible effects) }\end{array}$ & - & $\begin{array}{l}\text { co-costs (e.g. environmen- } \\
\text { tal costs), co-benefits (e.g. } \\
\text { recreational areas) }\end{array}$ \\
\hline & $\begin{array}{l}\text { compensation, disaster re- } \\
\text { lief }\end{array}$ & compensation, disaster relief & - & $\begin{array}{l}\text { risk transfer, financial incen- } \\
\text { tives, insurance premiums }\end{array}$ \\
\hline
\end{tabular}

Table 2. Overview of private and public cost benefactors (payers) of natural hazards in Austria; based on concepts of Kienholz et al. (2004) and The World Bank (2010).

\begin{tabular}{|c|c|c|c|c|}
\hline & \multicolumn{2}{|c|}{ post-disaster spending/costs for coping } & \multicolumn{2}{|c|}{ pre-disaster spending/costs of mitigation } \\
\hline $\begin{array}{l}\text { stage of risk } \\
\text { cycle }\end{array}$ & $\begin{array}{l}\text { emergency management and } \\
\text { response, (intervention) }\end{array}$ & $\begin{array}{l}\text { reconstruction and recovery, } \\
\text { (recondition and reconstruc- } \\
\text { tion) }\end{array}$ & risk analysis & $\begin{array}{l}\text { prevention (mitigation) and } \\
\text { preparedness }\end{array}$ \\
\hline $\begin{array}{l}\text { main cost } \\
\text { category }\end{array}$ & variable operational costs & variable damage and losses & $\begin{array}{l}\text { planning costs and decision } \\
\text { support - fixed costs }\end{array}$ & $\begin{array}{l}\text { costs of risk reduction - } \\
\text { fixed costs }\end{array}$ \\
\hline \multirow[t]{4}{*}{ examples } & $\begin{array}{l}\text { regional and national emer- } \\
\text { gency departments, civil } \\
\text { protection, municipalities }\end{array}$ & $\begin{array}{l}\text { national, federal states, dis- } \\
\text { tricts, municipalities }\end{array}$ & $\begin{array}{l}\text { public administration at all } \\
\text { levels (ministries, public } \\
\text { agencies, federal states, } \\
\text { districts, municipalities) }\end{array}$ & $\begin{array}{l}\text { public administration at all } \\
\text { levels (ministries, public } \\
\text { agencies, federal states, } \\
\text { districts, municipalities) }\end{array}$ \\
\hline & Red Cross, fire departments & companies & companies & companies \\
\hline & $\begin{array}{l}\text { police, armed forces } \\
\text { public health care }\end{array}$ & private households & $\begin{array}{l}\text { insurances } \\
-\end{array}$ & private households \\
\hline & $\begin{array}{l}\text { volunteers/private house- } \\
\text { holds (no compensation, } \\
\text { private costs) } \\
\text { companies }\end{array}$ & & & \\
\hline
\end{tabular}


hazards on an annual basis and the consecutive effectiveness of the installed mitigation and applied strategies in risk reduction to reduce adverse effects. The question is whether the government spends enough resources (depending on societal needs) to mitigate natural hazards. So, the fixed annual costs of mitigation as a whole have to be estimated by a proactive and comprehensive approach (Benson and Clay, 2004). Moreover, for a holistic cost assessment of natural hazards, the fixed and variable costs on aggregated levels have to be taken into account to serve a basis for future risk prevention strategies.

\section{Regional evidence for costs of Alpine hazards mitigation}

Costs of mitigation include the preparation of mitigation measures (e.g. risk analysis, planning costs and decision support) and the implementation of the results for technical and non-technical mitigation and preparedness (Table 1). Public expenditures on disaster and risk management are difficult if not impossible to measure (Benson and Clay, 2004). In Austria, many administrative bodies at all levels (national, federal state, district, and municipality), ministries, and public agencies with scattered competences (e.g. environment, health, civil protection, and avalanche and torrent protection) are involved in hazard and risk management (RudolfMiklau, 2009). These institutions have their own budgets and they do not account for the expenditure on public mitigation against natural hazards as a single budget item, but take their own decisions (The World Bank, 2010). In addition, companies as well as private households pay for (their) safety, but these expenses are usually not reported systematically. Analysing costs of prevention and mitigation needs sustained efforts to combine annual public budgets from diverse legal and budgetary settings. At least for Austria, a comprehensive overview of the planning system of natural hazard mitigation can be found in Holub and Fuchs (2009) focusing on legal settings, involved institutions, hazard zoning and risk transfer.

Despite the studies on local mitigation measures and their costs for avalanche protection, as already discussed in the introduction and section two, only very few studies exist to date that have estimated annual expenditure on natural hazard protection at an aggregated level.

Governmental expenditure in the case of flood protection in different countries around the North Sea (Denmark, Germany, Netherlands, Flanders/Belgium, England) was analysed by SAFECOAST (2008). The study calculated an average of less than 0.1 per cent of GDP as government spending for mitigation infrastructure for the period 2000 to 2006. For the Alpine Space, a comprehensive study was carried out by Wegmann et al. (2007), embedded in the national strategy dealing with natural hazards and done by the Swiss Platform for Natural Hazards (PLANAT) revealing an annual expendi- ture of 0.6 per cent of GDP. The authors quantify the costs of floods, avalanches, geologic mass movements, earthquakes, thunderstorms, storms, and extreme temperatures by classifying the costs to four types of measures and two types of actors (public, private). The types of measures are adjusted to the model of integral risk management (risk management cycle, PLANAT, 2004): prevention (spatial planning, biologic measures, and technical mitigation), prevention for intervention (emergency planning, civil protection), prevention for regeneration (insurance, financial prevention, donations), and development of basic knowledge (research and development). The study by Wegmann et al. (2007) uses different methodological approaches, such as an analysis of statistical data, about 80 personal interviews with responsible institutions, and estimates based on extrapolations. Possible short-term investments as a result of hazard events were normalized by applying average values of a fictive year between 2000 and 2005. What is important is the relative share of the different stakeholders, types of risks, and types of measures to be able to have quantitative data for a discussion on public expenses for safety from natural hazards in Switzerland. Annually, about three billion Swiss francs (approx. EUR 2.5 billion) are spent on mitigation against natural hazards. The private sector (insurance) bears about 59 per cent of the total costs. CHF 1.2 billion (approx. EUR 1 billion) are spent by the public administration at different levels (Wegmann et al., 2007). Analysed by type of measures, not surprisingly, most of the money is spent on mitigation measures (about CHF 1.3 billion, approx. EUR 1 billion, 45 per cent of the total costs). 37 per cent of the costs are disbursed for prevention for generation, 14 per cent for prevention for intervention, and only four per cent for research and development. Compared with the annual public budget of Switzerland, less than 1 per cent is spent on mitigation against natural hazards (Wegmann et al., 2007). Of course, such analyses are accompanied by uncertainties and different levels of accuracy. However, the results reveal the shares of different stakeholders, risks, and types of measures for reducing risks of (Alpine) hazards.

\subsection{Fixed annual costs for public safety against Alpine hazards}

Due to the scale and comparability of analysing costs for mitigation and emergency, but also for a deeper insight into the different cost categories in the case of Alpine hazards (Table 1), further data analyses are needed on an annual basis to quantify and benchmark the costs of mitigation against natural hazards. We analysed four different regions with variable shares of mountain areas, and different institutional and legal settings for mountain hazards (Fig. 1). Finally, the total cost of public safety is calculated in absolute terms, per area, per capita and in per cent of gross domestic product and/or gross regional product to benchmark the public expenses. 


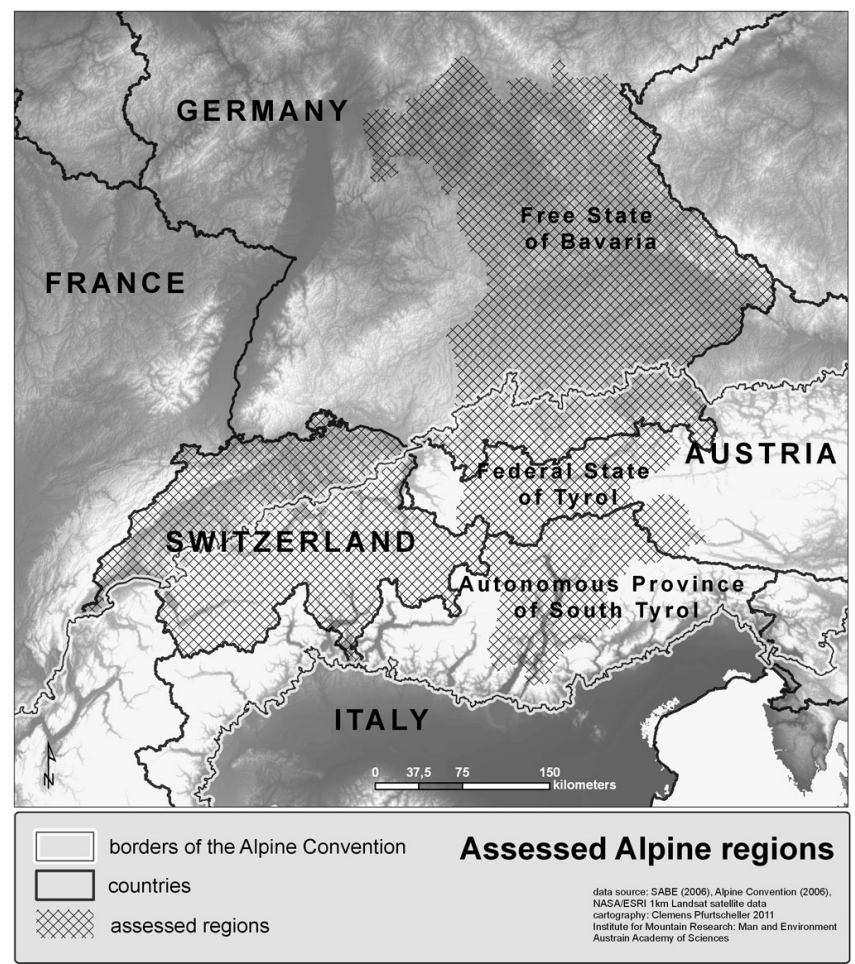

Fig. 1. Assessed Alpine regions: Free State of Bavaria (Germany), Federal State of Tyrol, (Austria), Autonomous Province of South Tyrol (Italy) and Switzerland.

Table 3 outlines the results of the analysis of fixed annual costs for public safety against Alpine hazards (mainly flash floods, floods, geologic mass movements, and avalanches) in Bavaria (Germany), Tyrol (Austria), South Tyrol (Italy), and Switzerland to get an overview of proportions at federal and regional level. Due to different sources and availability of the data at the time of analysis, we compiled different years from 2007 to 2010. For the explanatory power of the results, the different reference years will not make huge differences, e.g. the real changes in producer and import prices in Switzerland is only about 4.6 per cent from 2005 to 2010 using data provided by the Swiss department for statistics. The bases of this compilation are the country-specific public expenses, which can be found in budgets of the departments in charge of natural hazard management.

The data of the analysis stem from official budgets of the assessed regional government departments responsible for risk management, mitigation and emergency in case of natural hazards (see Appendix A for a detailed overview and sources) and are compared with Swiss data provided by Wegmann et al. (2007). In practice, these categories cannot be found in public budgets or cannot be correlated to it easily, but are analysed in Table 3, where possible, by assigning them to the different broader categories.

The table is structured as follows: the "mitigation" section includes all public expenses at the level of provinces/federal states for the pre-disaster costs of risks (costs of risk reduction, planning costs and decision support, see categorization Table 1). In the main, this category includes investment and construction costs of technical mitigation and related infrastructure, and costs for operation, use, maintenance and disposal of these measures. Additional cost categories of technical mitigation measures, such as planning, design, research and development, investment cannot be subdivided and hence are included in the broader category of "mitigation". Nevertheless, these costs are needed to carry out cost-benefit-analyses for mitigation measures, but there is no public access to data on individual mitigation projects. Subcategories of these projects are: construction period, period of investigation, planning costs, construction costs, transfer money, costs for reinvestment depending on the physical life of the facility, and maintenance costs to calculate net present values of the mitigation project (Federal Ministry of Agriculture, Forestry, Environment and Water Management, 2008a, b). Similar to that, the different levels of public authorities (national, federal state/canton, district, municipality), which are in charge of natural hazard management, also pay differently for technical mitigation measures. In Austria, on average, 65 per cent of the costs of technical mitigation measures against Alpine hazards are paid by the federal government (ministries), 21 per cent by the regional governments, eight per cent by the municipality and, if involved, six per cent by a pool (e.g. private companies, public road administration, water associations) (Federal Ministry of Agriculture, Forestry, Environment and Water Management 2010 and authors' calculations).

The "emergency" section includes all costs for public and private emergency institutions (fire departments, control centre, first respond, air rescue service, emergency management, civil protection, avalanche warning and hydrographical service) including operation and training and costs of additional forces (army, police, volunteers). Costs of early warning, monitoring, awareness building and communication as part of the public duties in risk and hazard management are also included.

Co-costs and co-benefits are not included. These categories represent mostly non-market values, and hence, cannot be found in public budgets. Note that incurred costs of voluntary organizations have not been determined, because these (time-) costs are - at least in Austria - mainly paid by the volunteers themselves and their institutions, but will, from a macro-economic point of view, decrease the economic output of the region. However, most of these organizations receive public funding. Specifically, the fire departments in Austria and the Technisches Hilfswerk (THW) in Germany are funded by national ministries and regional governments or, like the THW, are federal agencies, but rely on a huge number of voluntary members.

The comment section of the table also describes the disparity between public budgets concerning Alpine risks across the reviewed countries. One cause for the largest differences 
Table 3. Overview of the fixed annual costs of public safety in the case of Alpine hazards in South Tyrol, Tyrol, Switzerland, and Bavaria in EUR PPP values, sources: see Appendix A.

\begin{tabular}{|c|c|c|c|c|c|}
\hline & categories & $\begin{array}{l}\text { Autonomous } \\
\text { Province of } \\
\text { South Tyrol, } \\
\text { Italy, PPP* }\end{array}$ & $\begin{array}{l}\text { Federal State of } \\
\text { Tyrol, Austria, } \\
\text { PPP* }\end{array}$ & $\begin{array}{l}\text { Switzerland } \\
\text { PPP* }\end{array}$ & $\begin{array}{lr}\text { Free } & \text { State } \\
\text { of } & \text { Bavaria, } \\
\text { Germany, PPP* }\end{array}$ \\
\hline \multirow{4}{*}{ mitigation } & mitigation total & 46552934 & 62825279 & 426059610 & 133620038 \\
\hline & mitigation total per area $\left(\right.$ EUR $\left.\mathrm{km}^{-2}\right)$ & 6292 & 4970 & 10320 & 1894 \\
\hline & mitigation total per capita & 92 & 90 & 55 & 11 \\
\hline & emergency total & 62188031 & 17308550 & 215503699 & 419832026 \\
\hline \multirow[t]{2}{*}{ emergency } & emergency total per area (EUR $\left.\mathrm{km}^{-2}\right)$ & 8405 & 1369 & 5220 & 5951 \\
\hline & emergency total per capita & 124 & 25 & 28 & 34 \\
\hline \multirow{10}{*}{$\begin{array}{l}\text { additional informa- } \\
\text { tion, basic data }\end{array}$} & year of data - costs for public safety & 2008 & 2010 & 2007 & 2009 \\
\hline & total area $\left(\mathrm{km}^{2}\right)$ & 7399 & 12640 & 41285 & 70552 \\
\hline & Alpine area $\left(\mathrm{km}^{2}\right)$ & 7399 & 12640 & 25211 & 11160 \\
\hline & $\begin{array}{l}\text { share of Alpine areas of total area as defined } \\
\text { by the Alpine Convention }\end{array}$ & $100 \%$ & $100 \%$ & approx. $60 \%$ & approx. $16 \%$ \\
\hline & total population & 503434 & 698377 & 7785800 & 12510331 \\
\hline & population density & 68 & 55 & 189 & 177 \\
\hline & population in Alpine Areas (2007) & 503434 & 698377 & 1830500 & 1484980 \\
\hline & year of data: population, GDP/GRP & 2009 & 2007,2009 & 2009 & 2009 \\
\hline & PPP based on EU-27 $(2009$, EU27 = 100) & 105 & 108 & 138 & 105.8 \\
\hline & GDP/GRP market prices in EUR & 17268999000 & 23866000000 & 369034599780 & 429862000000 \\
\hline \multirow{4}{*}{$\begin{array}{l}\text { total costs of public } \\
\text { safety }\end{array}$} & total costs & 108740964 & 80133829 & 641563309 & 553452063 \\
\hline & total costs per area (EUR km $\left.{ }^{-2}\right)$ & 14697 & 6340 & 15540 & 78445 \\
\hline & total cost per capita & 216 & 115 & 82 & 44 \\
\hline & total costs in per cent of GDP/GRP & 0.63 & 0.34 & 0.17 & 0.13 \\
\hline
\end{tabular}

* Purchasing Power Parities (PPPs) are currency conversion rates that both convert to a common currency and equalize the purchasing power of different currencies. In other words, they eliminate the differences in price levels between countries in the process of conversion; source: Eurostat - http://epp.eurostat.ec.europa.eu, based on EU-27 (= 100) average of 2009. Areas were calculated based on Permanent Secretary of the Alpine Convention (2010). GDP/GRP in market prices (EUR), conversion from SFR based on exchange rate of 14 December 2010. Sources are listed in the reference section. Please note that Wegmann et al. (2007) calculated the costs for natural hazard mitigation in Switzerland as 0.6 per cent of GDP. We use PPP values of these costs, and so the share is lower.

is whether the costs for maintaining and monitoring public water bodies in general are included or not, and perhaps these numbers will have a great impact on public spending on mitigation as a whole (e.g. see South Tyrol). Finally, most of the public departments responsible for hazard management are also in charge of other risks or man-made hazards (e.g. civil protection units, fire departments, rescue, etc.), so the costs for those are also included.

It is important to highlight that these numbers must be interpreted under the premise that administrative structures and regulatory/legal frameworks for natural hazard management implemented in these countries differ greatly. For instance, risk transfer in the case of natural hazards in Switzerland is mainly done by a compulsory, state-controlled building insurance, whereas in Austria a system of public funding and private insurance should absorb negative impacts on private assets (Vetters and Prettenthaler, 2004; Republik Österreich, 1996, see also Sect. 4.2.3). In 2010, the Austrian disaster fund had a budget of EUR 344 million for mitigation measures and compensation for private losses and business interruption (Federal Ministry of Finance, 2012). Hence, we focus on annual fixed costs of mountain hazards and we do not investigate costs (or payments) caused by natural hazard events (risk transfer/loss compensation payments). These payments can be insurance premiums and private and public compensations for losses, depending on the risk transfer system. Huge natural hazard impacts, like the flood events in 2002 and in 2005 in Austria, show that additional technical mitigation measures increase the governments' deficits through special funding on a legal basis as a result of reactive and event-based legislation (Federal Ministry of Finance, 2002, 2005). Again, within this study we focus on regional government spending on mitigation.

\subsection{Results}

Public expenditure varies greatly across the reviewed regions. Per capita and per area values calculated using PPP values (purchasing power parities are needed to equalize the purchasing power of different currencies) put the Free State of Bavaria with a spending of about EUR 44 for public safety against natural hazards in the assessed year at the bottom and the Autonomous Province of South Tyrol with about EUR 216 at the top of per capita spending. In this case, there is not much sense in comparing absolute figures, given the totally different natural/societal/economic/legal framework in these countries. Beyond that, the territorial share of Alpine environments in the reviewed countries also differs greatly, from approx. 16 per cent (Bavaria) to 100 per cent (Tyrol). 


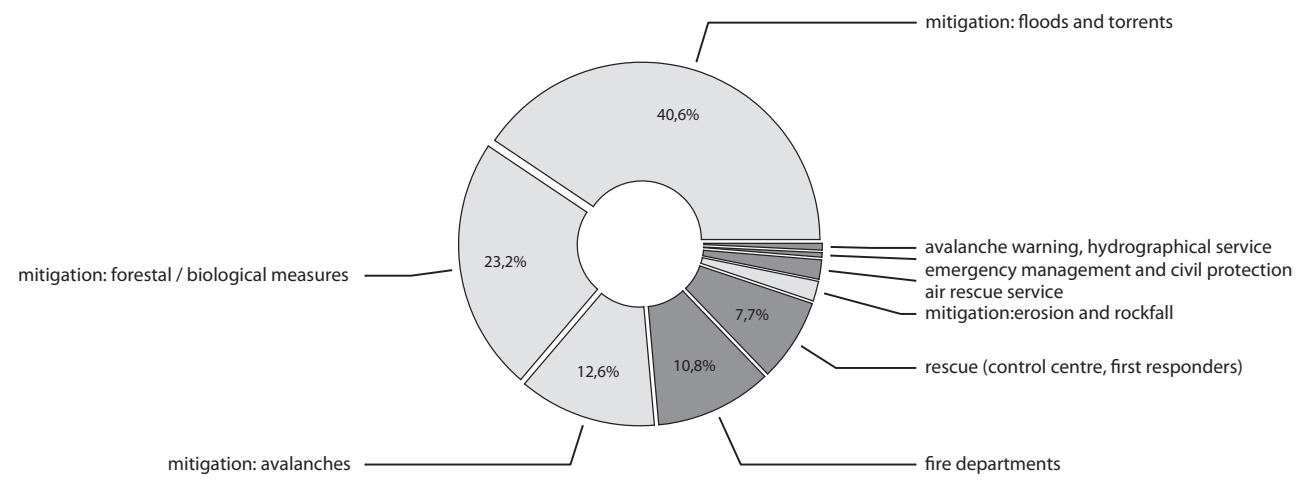

Fig. 2. Annual expenses in 2010 for public safety against natural hazards without wages and fixed assets in per cent for Tyrol, Austria (source: Federal State of Tyrol, 2010).

Hence, the exposure to Alpine hazards and the absolute and relative costs of mitigation measures for Alpine risks are quite different. We considered "total population" for those regions, where a distinction of the costs in Alpine vs. nonAlpine regions was not available. In public budgets of the assessed regions, only sums of measures are shown, not the regions where the costs arose. For example, in Bavaria the costs for torrent and avalanche protection are about EUR 27.2 million (in PPP values). If that is related to the 1.5 million residents in the Alpine regions of the Free State of Bavaria (Alpine Convention, 2010), the costs per capita are higher, i.e. approx. EUR 15, compared to EUR 11 using the total costs of mitigation and the total population of the Free State (Table 3). Please note that we assume here that all costs for torrent and avalanche mitigation arise in the Alpine region.

Analysing the costs for mitigation in the Federal State of Tyrol in more detail, approx. three quarters of the total sum is spent on technical and biological/forestal mitigation measures against Alpine hazards (Fig. 2). Rescue, emergency, and warning systems, plus civil protection as part of preparedness is a marginal cost factor, although prevention measures like warning, risk communication and education could reduce adverse hazard impacts.

With regard to the type of process, we tried to distinguish between Alpine (e.g. debris-flows, landslides, avalanches) and non-Alpine risks (e.g. floods) and their costs, but often it is not possible to make that distinction based on the official budgets. Hence, we analysed all costs for natural hazard spending including all types of processes.

Nevertheless, the results show a high variance, but also a certain range and partly a homogeneous scattering of public expenditure (Fig. 3). The Free State of Bavaria reports the lowest public costs of mitigation in per capita values. Obviously, Bavaria and Switzerland have a high population density and hence the lowest costs of mitigation. South Tyrol has an outstanding position in mitigation and emergency costs met from the public purse. Very high investments in risk mitigation against natural hazards in recent years are the main

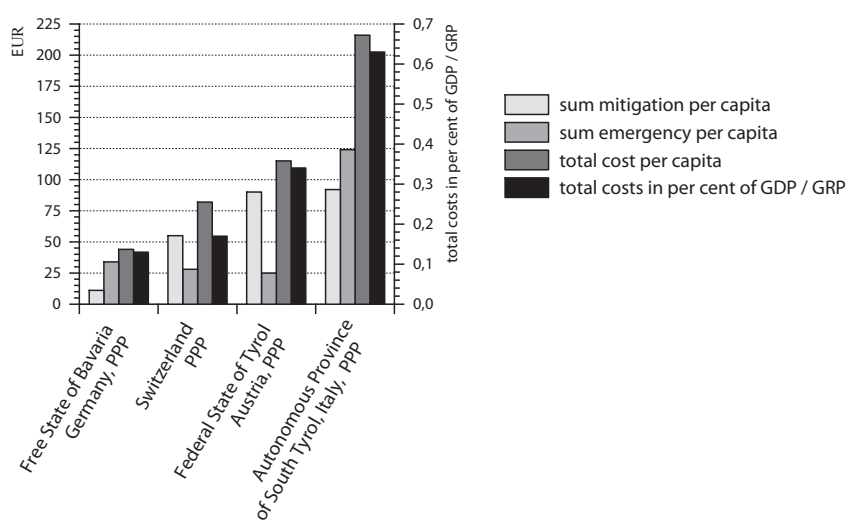

Fig. 3. Per capita expenditure for mitigation, emergency (in EUR PPP values, reference years: 2007-2010) and total costs in per cent of gross domestic/regional product.

reason for this, but also the fact that the emergency system is completely financed by public bodies.

If the expenses are compared with the countries' gross domestic/regional product, the highest share can be found in South Tyrol with approx. 0.63 per cent spent on public natural hazard management. This figure is more than four times that of Bavaria. Analysed as per total area values for the annual costs of mitigation and emergency, the results differ considerably (Fig. 4). For example Switzerland, South Tyrol and Tyrol have a huge share of high Alpine regions, and hence, high costs of public safety, but Tyrol has much lower costs of mitigation. At this point the different settings (e.g. large impact events) of the year of the analysis have to be reflected. It would be desirable to analyse a longer period and to be able to normalize short-term investment effects triggered by hazard events.

To conclude, on average the analysed countries with a share of the Alps spend about EUR 114 per year and capita and about EUR 11100 per year and $\mathrm{km}^{2}$ on ensuring public safety against natural hazards like flash floods, floods, torrent processes, gravitative mass movements and avalanches. 


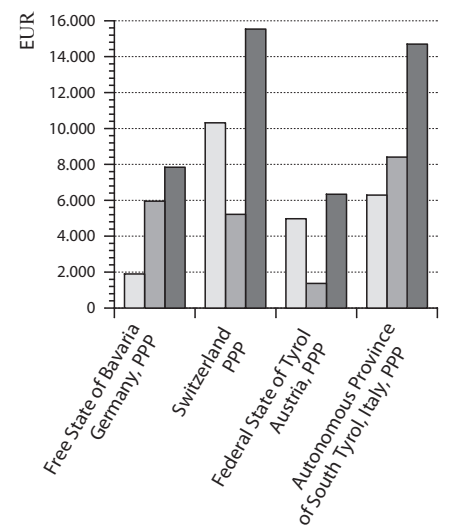

Fig. 4. Per area expenses for mitigation, emergency and total costs for public safety in $\mathrm{km}^{2}$ (in EUR PPP values, reference years: 20072010).

There are also highly different per capita costs of public safety (EUR 44 to 216). The reasons for the differences in the assessed regions are probably, first, considerably different exposure to Alpine natural hazards; second, different accepted and legally binding safety levels; and third, totally different administrative as well as organizational structures.

Much effort was needed to determine these costs. We must stress that these figures and cost categories should be interpreted as a rough estimate and approximation to the public costs because of various differences and peculiarities in the assessed countries (see above). The results do not judge the different risk management systems in the analysed regions (and do not rank the systems by their expenses), but rather serve as an approximation for assessing these cost categories. The total pre-disaster economic costs of natural hazards cannot be calculated exactly. Moreover, these values express the societal and political value of public safety from natural hazards. Further research is needed primarily to put the effectiveness and efficiency of the installed and planned mitigation strategies and single mitigation measures on a sound basis of balancing public expenses and society's needs for safety.

\section{Estimating the costs of emergency}

Emergency management aims at reducing the impacts of hazards when an event occurs. In addition to fixed costs, variable costs occur during and after events. For a complete cost assessment of natural hazards, the costs of emergency services also have to be estimated. This omission may seriously affect the relative economic benefits of, for example, structural versus non-structural measures of hazard mitigation. Accounting for the (avoided) costs of emergency services would in any case be an essential component for a comprehensive cost-benefit analysis of risk management programmes. Generally, a (high-impact) emergency is an exceptional event, which is beyond the resources of usual conditions and needs additional strengths and organizational settings to withstand the adverse effects of natural hazards by saving residents and protecting assets (Alexander, 2002). Hence, emergency management is the planned deployment of resources or a set of measures to cope with exceptional situations. Management of emergencies is a short-run action that ends when basic living conditions are restored. The duration of such situations mainly depends on the scale of the hazard process, lasting from hours to months (Alexander, 2002; EMA, 2004).

The following tasks are carried out by the emergency management when a hazardous event occurs: searching for/rescuing/evacuating humans, healthcare, traffic regulation and road barriers, upholding communication, maintaining transportation and supply (e.g. cleaning up roads, restoring electricity), providing shelter, food and water for the affected, and engineering measures for temporary/mobile protection as well as safeguarding structural features. The costs of management and response planning and the measures carried out can occur before, during and after an event. The fixed pre-disaster costs of emergency were already addressed in the previous section. This section focuses on the emergency response measures and on variable costs (post-disaster spending). There has been little research on cost functions and cost patterns of emergency services, despite the fact that the costs of emergency services can be substantial at both the meso and the macro level.

Different techniques have been developed to estimate costs of emergency services or parts of them. Much work has been done on hurricanes. Boswell et al. (1999) estimated the public (governmental) costs of hurricanes in Florida (US) on the basis of national reimbursements by multivariate regression using meteorological (surface wind speeds) and socio-economic variables. In detail they analysed the costs for debris removal, protective measures, traffic infrastructure, water control facilities, buildings and equipment, public utilities, and parks and recreation. These costs are direct losses, but they also analysed the costs of emergency response measures within the category of protective measures. The per capita public costs of response and recovery were calculated from nearly zero to USD 1139 (approx. EUR 813 - average 2011 values) dependent on the storm category (1 to 5). On the basis of opportunity costs of additionally needed traveling, time, and accommodation, Whitehead (2003) used household questionnaire data and modelling of evacuation behaviour to estimate the evacuation costs for hurricanes in North Carolina (US). The costs computed vary from USD 1 million (EUR 714000, category 1) to USD 50 million (EUR 35.7 million, category 5 storms). In the case of the 2005 hurricane Katrina, the approved government expenditure on emergency services amounted to more than USD 5 billion (EUR 3.6 billion) or 3.7 per cent of the total economic loss from this event.

Joy (1993) studied the direct and indirect costs of flooding in the city of Nyngan (New South Wales, Australia), where a major evacuation became necessary during and after 
the flooding. He reported evacuation costs of AUD 1.5 million (EUR 1.1 million), relief costs of AUD 8.4 million (EUR 6.3 million) and clean-up costs of AUD 2.1 million (EUR 1.6 million). Relief costs in Joy's study included services for evacuees, extra salaries of community employees, and financial support for evacuated people.

For floods and coastal risks, the "Multi-Coloured Manual" for project appraisal of mitigation techniques (PenningRowsell et al., 2005a, b, based on Penning-Rowsell and Wilson, 2006) offers a broad view of the benefits of determining emergency and related costs, based on empirical data of the total costs of flood control from 58 counties in the UK during a major flood event in 2000. They analysed the costs of emergency management, of safeguarding buildings and infrastructure, as well as the costs of search and rescue operations. Previous work on the "Multi-Coloured Manual" (the "Red Manual", Parker et al., 1987) estimated the average costs of the emergency as approx. GBP 1017 (2005 prices, approx. EUR 864 at 2011 prices) per flooded property. Moreover, they pointed out that the more properties are flooded, the lower are the average costs. Alternatively, the costs of the 2000 floods in the UK can be used to estimate benchmarks for the costs of emergency. In that case, 10.7 per cent of the property losses of the flood event (modelled with a financial model) were identified as a suitable factor for flood project appraisals (12.5 per cent of property losses modelled with an economic model, see PenningRowsell and Wilson, 2006). They suggest multiplying the total direct loss by 1.107 to arrive at the full losses, including the emergency costs. Penning-Rowsell et al. (2005a, b) also introduced a checklist for aftermath assessments of emergency costs. They suggested surveying emergency services for staff needed, service hours worked, wages paid, vehicles and equipment used, and diverse other costs related to the flood event. As an important part of emergency costs, evacuation expenses were analysed separately. Using contingent valuation, Zhai and Ikeda (2006) analysed the willingness-topay (WTP) for avoiding the inconvenience of evacuation in the case of flood events in Japan. They surveyed randomly distributed households in recently affected areas (NiigatFukushima flood, Fukui flood and a typhoon in Toyo'oka). The authors computed a willingness to pay of JPY 2340 (approx. EUR 21.3, 2011 prices) per day and person. Nearly the same figure was observed during the floods of 2004 (approx. JPY 2688, EUR 24.4). Nevertheless, they concluded that the economic costs of evacuation were nearly twice the WTP, stating that public budgets for evacuation were too small.

There has been only little research on emergency costs of Alpine hazards. One exception is the study by Fuchs et al. (2007), which estimated the cost of evacuation within the framework of cost-benefit-analysis for alternative avalanche risk reduction measures including land-use planning and organizational measures (especially evacuation). The costs for a certain area in Switzerland were computed by multiplying hourly wages and number of emergency staff, average time

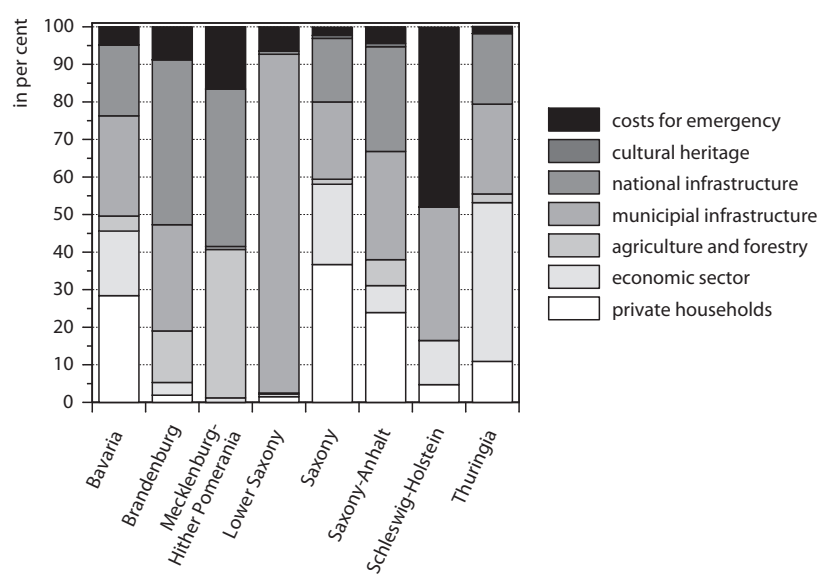

Fig. 5. Share of different damage categories of the 2002 floods in the federal states of Germany; source: estimates as at 2003 were reported to EU solidarity fund.

needed to carry out the evacuation, and number of buildings, plus the costs of food and shelter, multiplied by the number of persons and days. This resulted in costs for evacuation per residential building at CHF 320 (approx. EUR 267, 2011 prices). An overview of clean-up costs (and costs of mitigation) is given by Oberndorfer et al. (2007) and compared with the total direct losses in case of torrent events in Austria.

\subsection{Emergency costs of river flooding - the flood in 2002 in Germany}

There is also little evidence from national, regional and local governments reporting emergency costs triggered by natural hazards. The 2002 floods in Germany caused about EUR 11.6 billion in direct losses (W. Kron, personal communication, 2011, based on IKSE 2004 and other information from public agencies). Earlier estimates of the 2002 floods state about EUR 7.7 billion in total loss, including emergency costs and other categories (Table 4).

We used the 2003 estimates to calculate the share of emergency costs, since no categorization of the losses is available for the 2005 estimate of the 2002 floods. Analysing the emergency costs relatively to the direct costs, we arrived at a mean share of 17.8 per cent (median 6). Using the 2005 total loss estimates without deeper categorization (W. Kron, personal communication, 2011, based on IKSE 2004 and other information from public agencies), we calculated a mean share of 10.9 per cent (median 5, Table 4). On the basis of the 2003 loss estimates, the share of emergency expenses varied greatly (Fig. 5).

The direct loss data of Germany represent reconstruction values, whereas the values from the UK are actual cash values (Penning-Rowsell and Wilson, 2006), which might distort the shares. These differ due to the change of the loss estimates for Germany. Taking into account that the estimates of emergency costs are very accurate, the shares based on 
Table 4. Estimated loss data of the 2002 floods in the affected federal states of Germany without the figures for the national loss; source: estimates as at 2003 were reported to EU solidarity fund; estimates as at 2005 are based on IKSE 2004 and W. Kron, personal communication, 2011.

\begin{tabular}{|c|c|c|c|c|c|c|c|c|c|}
\hline in EUR millions & Bavaria & Brandenburg & $\begin{array}{r}\text { Mecklenburg-Hither } \\
\text { Pomerania }\end{array}$ & $\begin{array}{r}\text { Lower } \\
\text { Saxony }\end{array}$ & Saxony & $\begin{array}{l}\text { Saxony } \\
\text { Anhalt }\end{array}$ & $\begin{array}{r}\text { Schleswig } \\
\text { Holstein }\end{array}$ & Thuringa & total \\
\hline private households & 56.0 & 2.7 & 0.0 & 2.6 & 2234.6 & 245.7 & 0.2 & 5.3 & 2547.1 \\
\hline economic sector & 34.0 & 4.9 & 0.4 & 1.2 & 1302.3 & 73.6 & 0.5 & 20.7 & 1437.6 \\
\hline agriculture and forestry & 7.8 & 19.8 & 13.0 & 0.4 & 78.5 & 71.3 & 0.0 & 1.1 & 192.0 \\
\hline municipal infrastructure & 52.7 & 40.9 & 0.3 & 157.2 & 1255.4 & 296.5 & 1.5 & 11.7 & 1816.2 \\
\hline national infrastructure & 37.4 & 63.6 & 13.8 & 1.4 & 1027.4 & 287.5 & 0.0 & 9.2 & 1440.3 \\
\hline cultural heritage & 0.0 & 0.0 & 0.0 & 0.0 & 49.8 & 9.2 & 0.0 & 0.0 & 59.0 \\
\hline costs for emergency & 9.5 & 12.8 & 5.5 & 11.4 & 136.4 & 45.5 & 2.0 & 0.9 & 223.9 \\
\hline total direct loss & 187.9 & 131.9 & 27.4 & 162.9 & 5948.0 & 983.8 & 2.2 & 48.1 & 7492.2 \\
\hline total loss (2003 estimate) & 197.4 & 144.7 & 32.9 & 174.3 & 6084.4 & 1029.3 & 4.2 & 49.0 & 7716.2 \\
\hline $\begin{array}{l}\text { share of emergency costs of to- } \\
\text { tal direct loss } \\
\text { in per cent (based on } 2003 \text { esti- } \\
\text { mate) }\end{array}$ & 5.1 & 9.7 & 19.9 & 7.0 & 2.3 & 4.6 & 91.8 & 1.9 & 3.0 \\
\hline total loss (2005 estimate) & 198.0 & 242.0 & 41.0 & 185.0 & 8700.0 & 1187.0 & 4.0 & 60.0 & 10617.0 \\
\hline $\begin{array}{l}\text { change to } 2003 \text { estimate of total } \\
\text { loss in per cent }\end{array}$ & $0.3 \%$ & $67.3 \%$ & $24.6 \%$ & $6.1 \%$ & $43.0 \%$ & $15.3 \%$ & $-5.2 \%$ & $22.5 \%$ & $37.6 \%$ \\
\hline $\begin{array}{l}\text { share of emergency costs of to- } \\
\text { tal direct loss } \\
\text { in per cent (based on } 2005 \text { esti- } \\
\text { mate) }\end{array}$ & 4.8 & 5.3 & 13.3 & 6.2 & 1.6 & 3.8 & 50.5 & 1.5 & 2.1 \\
\hline
\end{tabular}

the 2005 estimates of the 2002-flood may be more realistic. Hence, approximately 10 to 12 per cent of the total direct loss (median 5 to 6 per cent) serves as an approximation to estimate emergency costs in the case of inland river floods. On average, the percentage share of emergency costs is lower when overall direct costs are high and it is thus not feasible to assume a fixed percentage of emergency costs.

To conclude, the findings of the studies on emergency and evacuation costs cannot easily be compared due to the totally different socio-economic and hazard-specific settings and availability of data. They cannot serve as a basis for estimating public emergency spending in the case of Alpine hazards. Nevertheless, nearly all of these studies underline the importance of estimating emergency costs. The empirical basis, at least in Austria and Germany, for estimating these costs and their drivers in economic terms is still missing along with some basic data in the aftermath of high impact events. The main reasons for this shortcoming is likely to be the split responsibility of different statutory and voluntary organizations for emergency services, such as national civil protection agencies, army, voluntary local fire brigades, Red Cross, etc., and the missing legal basis to account for it.

\subsection{The case study of the 2005 floods in the Federal State of Tyrol (Austria)}

As introduced in the former section, empirical evidence on costs of emergency is largely missing, especially for Alpine hazards. We analyse the sum of costs as they accrue to the fire departments, omitting the costs of other national/regional/local and voluntary private emergency ser- vices in the 2005 flood event in the Federal State of Tyrol (Austria). We focus on data of the fire departments, since these organizations are primarily responsible for floods and related hazards in Austria. While our approach serves as a method to compare emergency spending between municipalities, we also try to identify the drivers of these costs in mountain areas.

\subsubsection{The 2005 floods}

The catastrophic flood event in Tyrol (Austria) in August 2005 caused an estimated total economic loss of EUR 410 million (Central Auditing Authority of the Federal State of Tyrol, 2006). That represents 2.1 per cent of the gross regional product (GRP) (2002 basis, total GRP: EUR 19.2 billion). The main characteristics of flood events in Alpine regions are the high impact on private households and structures and the destruction, partly or in full, of infrastructure like railways and roads. The flooding in 2005 in Tyrol can be separated into two processes. On the one hand, rock fall, landslides and debris/mud flows in mountain regions and, on the other hand, flooding and rising ground water levels in glacier formed valleys and low terrain formed loss characteristics. It seems to be typical for Alpine regions that the combination and mixture of processes trigger the high total economic losses caused by two flood events. In August 2005, a surplus in precipitation, partly with measured high intensities of more than $10 \mathrm{~mm} \mathrm{~h}^{-1}$ (daily precipitation rates of more than $100 \mathrm{~mm}$ in the west of Tyrol), and single return periods of water gauges of $5000 \mathrm{yr}$ resulted in large-scale inundations and high process intensities and therefore, high direct 
losses (Federal State of Tyrol, 2005 and Federal Ministry of Agriculture, Forestry, Environment and Water Management, 2006). Internal reports of the fire departments due to missing published data stated that approximately 320000 mission hours were needed to deal with the emergency, clean-up and evacuation. This translates into up to 13400 persons at work per day, including fire departments and additionally about 1500 members of the armed forces, police and Red Cross (A. Gruber, personal communication, 2008).

\subsubsection{Study design and empirics}

For the post-disaster spending it is necessary to count only the marginal (extra-occurring) costs (Penning-Rowsell et al., 2005a, b). Marginal costs of emergency services during flood events are only those costs that accrue as part of the emergency operation. Normal operating costs of the emergency infrastructure, however, should not be considered. These fixed costs were analysed in Sect. 3. Typical examples of marginal costs are overtime payments for professional emergency personnel, hiring of private contractors (e.g. for cleanups) and material, the operating costs and loss of vehicles and material of fire departments during the flood event, etc. A detailed overview of categories of post-disaster spending can be found in Table 1. Besides the costs of professional organizations, private costs may result from voluntary working hours during and after hazard events. Neighbourly help and similar voluntary services, e.g. providing shelter and food for evacuees or clean-up, are not paid at all, but are of economic relevance. These costs are mainly borne by the volunteers themselves and their employers as lost added value and therefore are reflected in the gross regional product.

Due to the diverse and interwoven tasks of the fire departments before, during and after hazard events, we distinguish costs for evacuation, safeguarding and clean-up (see also Table 1). It is important to mention that the fire departments in Austria are organized by the federal states on a legal basis, which describes the possible activities, and duties (fire department act, Landes-Feuerwehrgesetz, 2001). The staff of the fire departments is primarily voluntary, except for fire departments in bigger cities. There are also private fire departments of some companies, which are mandatory if the company staff exceeds a certain number of employees.

This study relies primarily on a questionnaire circulated among local fire departments in the aftermath of the 2005 flood $\left(n_{\text {total }}=325, n_{\text {returned }} 51 \%\right)$. These data are spatially matched with municipality areas due to different classification, e.g. in some cases one municipality consists of several fire departments. As also suggested by Penning-Rowsell et al. (2005a, b), we analysed central indicators of the local fire departments as the prime resilience infrastructure against flooding, such as operational effort, by means of hours worked ("service_hours"), the percentage of cleanup activities of total service hours ("clean_up"), staff involved ("staff"), vehicles used ("vehicles_used"), the dura- tion of the flood event in days of declared emergency ("duration"), the material, monetary losses of the relevant departments ("loss_fd") and "special" event characteristics like overtopped dams, damages due to bed load or till, debris flows and log jams or a combination of processes (e.g. occurrence of multiple hazards). For the analysis of spatial entities, we used permanent settlement areas and inhabitants of the municipalities to identify possible correlations to emergency efforts undertaken during the 2005 flood.

We used multiple regression equations to investigate the possible drivers of emergency costs. As empirical evidence and similar studies are missing, we assumed that the costs of emergency depend largely on the total permanent settlement area, the duration of the emergency situation, and the spatial extent of flooded areas. Since appropriate data are missing, we used the spatial extent of flooded areas to estimate the effects on service hours, clean-up, and losses of the fire departments. We are aware that possible channel sections, confined valleys, effects of erosion, and sediment accumulation could also have a strong impact on the dependent variables. Hence, special event characteristics were needed to distinguish between inland and Alpine floods, which are also accompanied by different processes.

From this we derived the following set of regressions:

$$
\begin{aligned}
& \log \text { (service_hours) }=\beta_{0}+\beta_{1} \log \text { (inhabit) }+\beta_{2} \log \text { (area) } \\
& +\beta_{3} \log \text { (duration) }+\beta_{4} \log \text { (area_flooded) }+\beta_{5} \text { (loss_fd) } \\
& +\beta_{6}(\text { special })+\varepsilon \\
& \log (\text { clean_up })=\beta_{0}+\beta_{1} \log (\text { inhabit })+\beta_{2} \log (\text { area })+ \\
& \beta_{3} \log \text { (duration) }+\beta_{4} \log \text { (area_flooded) } \\
& +\beta_{5}(\text { special })+\varepsilon \\
& \log \left(\operatorname{loss} \_ \text {fd }\right)=\beta_{0}+\beta_{1} \log (\text { inhabit })+\beta_{2} \log (\text { area })+ \\
& \beta_{3} \log \text { (duration) }+\beta_{4} \log \text { (area_flooded) }+\beta_{5} \log \text { (staff) } \\
& +\beta_{6} \log \text { (vehicles_used) }+\varepsilon
\end{aligned}
$$

where $\log$ ("service_hours"), $\log$ ("clean_up") and $\log$ ("loss_fd") are the logarithmic values of total staff hours provided by the fire departments per municipality, clean-up activities in per cent of total staff hours, and direct monetary losses occurred at the fire departments (lost material, damage to vehicles, etc.), respectively. The data of the study includes published statistical data - permanent settlement areas, inhabitants per municipality by Statistic Austria, and GIS data describing the flood event ("area_flooded"), which were digitized on the basis of aerial photographs during and after the flood event and provided by the Institute of Geography, University of Innsbruck.

\subsubsection{Results}

We used the costs of emergency services as a measure for the municipal capacity to mitigate losses and maintain normal living conditions after a natural hazard occurred as well as to manage recovery from the impact. Generally, our main 
Table 5. Descriptive statistics of the variables used.

\begin{tabular}{lrrrrrrr}
\hline variable and description (unit) & obs & range & min & max & sum & mean & std. e. \\
\hline area - permanent settlement area (hectare) & 246 & 3088.8 & 7.06 & 3095.9 & 132820.9 & 540 & 425 \\
inhabit - inhabitants & 246 & 116815 & 66 & 116881 & 646814 & 2629 & 7688 \\
area_flooded - flooded areas (hectare) & 246 & 231 & 0 & 231 & 1325 & 5.4 & 23.7 \\
duration - duration emergency (days) & 121 & 7 & 0 & 7 & 119 & 1 & 1.1 \\
service_hours (hours) & 125 & 50175 & 0 & 50175 & 192927 & 1543.4 & 6221.8 \\
Staff & 127 & 259 & 0 & 259 & 9966 & 78.5 & 42.4 \\
clean_up (in per cent of total service hours) & 119 & 100 & 0 & 100 & - & 25.9 & 25.6 \\
vehicles_used (used vehicles during the floods) & 128 & 70 & 0 & 70 & 630 & 4.9 & 7.5 \\
losses_fd (direct loss fire dep. in EUR) & 109 & 25000 & 0 & 25000 & 212069 & 1945.6 & 4129.9 \\
Special (qualitative) & 128 & 1 & 0 & 1 & - & - & - \\
\hline
\end{tabular}

Table 6. Model and results overview.

\begin{tabular}{|c|c|c|c|c|c|}
\hline \multicolumn{2}{|c|}{$\log$ (service_hours) } & \multicolumn{2}{|c|}{ log(clean_up) } & \multicolumn{2}{|c|}{ log(loss_mat) } \\
\hline coefficient & -9954.729 & coefficient & 2.35 & coefficient & 3.87 \\
\hline $\log$ (inhabit) & $\begin{array}{r}0.489 \\
(0.577)\end{array}$ & $\log$ (inhabit) & $\begin{array}{r}0.06 \\
(0.151)\end{array}$ & $\log$ (inhabit) & $\begin{array}{l}-0.233 \\
(0.357)\end{array}$ \\
\hline $\log ($ area $)$ & $\begin{array}{r}12.912^{* *} \\
(5.352)\end{array}$ & $\log ($ area $)$ & $\begin{array}{l}-0.141 \\
(0.175)\end{array}$ & $\log ($ area $)$ & $\begin{array}{l}-0.025 \\
(0.551)\end{array}$ \\
\hline duration & $\begin{array}{c}3197.156^{*} \\
(1655.294)\end{array}$ & $\log$ (duration) & $\begin{array}{r}0.372 \\
(0.329)\end{array}$ & $\log$ (duration) & $\begin{array}{r}1.652^{*} \\
(0.59)\end{array}$ \\
\hline $\log$ (area_flooded $)$ & $\begin{array}{r}3.355 \\
(28.511)\end{array}$ & $\log$ (area_flooded $)$ & $\begin{array}{r}0.366^{* * *} \\
(0.114)\end{array}$ & $\log$ (area_flooded) & $\begin{array}{c}0.452^{*} \\
(0.227)\end{array}$ \\
\hline losses_fd & $\begin{array}{r}0.054 \\
(0.102)\end{array}$ & & & & \\
\hline \multirow[t]{3}{*}{ special } & $\begin{array}{c}6164.934^{*} \\
(3560.188)\end{array}$ & special & $\begin{array}{l}0.432^{*} \\
(0.249)\end{array}$ & & \\
\hline & & & & $\log ($ staff $)$ & $\begin{array}{r}0.461 \\
(0.344)\end{array}$ \\
\hline & & & & $\log ($ verhicles_used) & $\begin{array}{r}0.855^{*} \\
(0.4)\end{array}$ \\
\hline$n$ & 38 & & 33 & & 21 \\
\hline$R$ squared & 0.464 & & 0.497 & & 0.698 \\
\hline$R$ squared $_{\mathrm{adj}}$. & 0.36 & & 0.404 & & 0.569 \\
\hline$F$ stat. & 4.454 & & 5.341 & & 5.4 \\
\hline prob. ( $F$ stat. $)$ & 0.002 & & 0.002 & & 0.004 \\
\hline
\end{tabular}

$* 10 \%,{ }^{* *} 5 \%,{ }^{* * *} 1 \%,{ }^{* * * *} 0,1 \%$ significance.

finding here is that the flood duration and the occurrence of multiple hazards have both a significant impact on the total hours spent and, thus, the costs of emergency services (Table 6). Multiple hazards force the fire departments to have multiple sites of operation and increase service hours. The share of clean-up costs is driven by flood intensity (measured by inundated area) and the coincidence of multiple hazards. The duration of the emergency period, however, shows a strong impact, with a great margin of error, so that its effect is not statistically significant. Unobserved characteristics of the location (such as the structure of housing, proportion of timber frame houses versus stone houses, etc.) also seem to have a great effect on the cost of clean-up, since our set of variables only explains less than half of the variance observed in our data. In our sample, the loss in material (damage to cars, machines, safeguarding material, etc.) is driven overridingly by the number of days of the event and to a lesser extent by the flood intensity (measured by the inundated area). It is also significantly affected by the number of vehicles used in the emergency operation, but, surprisingly, not significantly by number of persons in action.

Apart from multiple regressions results, which serve as basic evidence for the triggers of emergency expenses, the costs of emergency can be computed by summing up the monetary equivalent of service hours, i.e. service hours multiplied with an average hourly wage of EUR 20 . This is the rate charged by the federal fire brigade association in Tyrol (2010). Vehicles and material are charged separately and added to the 


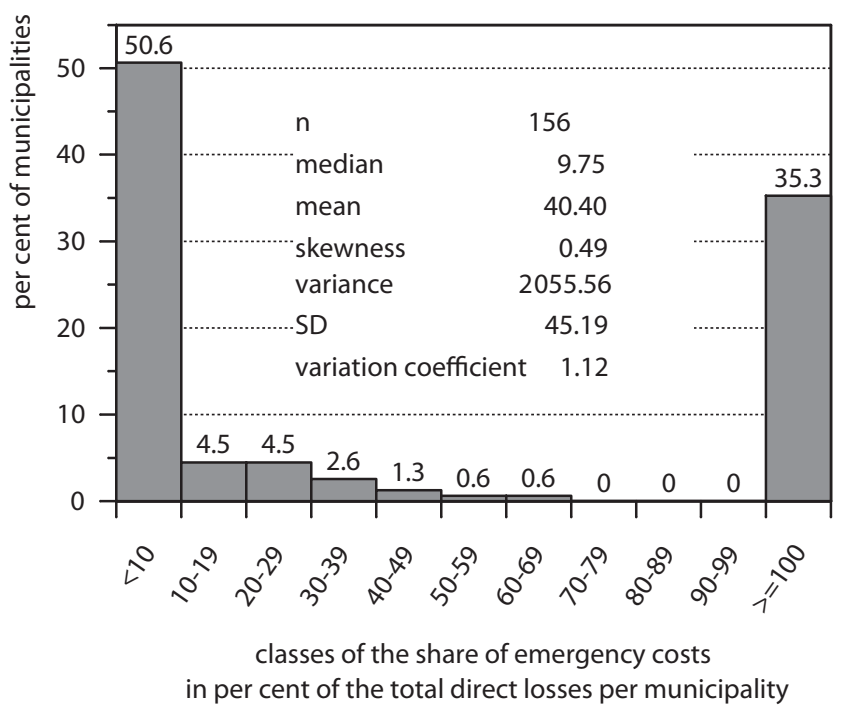

Fig. 6. Histogram of the share of emergency costs in per cent of the total direct losses per municipality (data source: questionnaire results and direct losses of private households and companies provided by the Federal State of Tyrol, Austrian Disaster Fund Act).

service hour wages. In the case of natural hazards, these costs of service hours were not invoiced, but arose as economic costs. Based on questionnaire data, we calculated the total emergency costs of the fire brigades as approx. EUR 2.4 million and compared it with the direct losses incurred in the surveyed municipalities (EUR 126 million), neglecting costs of other organizations responsible for disaster management. These data stem from estimates of the direct losses of private households and companies and were provided by the federal state, based on the Austrian Disaster Fund Act as a basis for disaster relief (Republik Österreich, 1996). The risk transfer system in Austria is organized on this fund and on private insurances, although private insurances rarely cover floods and similar processes (Gruber, 2008; Holub and Fuchs, 2009). The disaster fund is financed by taxes and additional resources in case of exceptional hazard events (Vetters and Prettenthaler, 2004; Fuchs, 2009). The fund does not solely compensate direct losses of private households, companies and municipalities. Most of the budget is spend on mitigation measures against floods, avalanches and torrent events. This system suffers from noticeable shortcomings (Prettenthaler und Vetters, 2005). Extraordinary events can bust the fund (as happened in 2005), different loss claim procedures in the federal states aggravate the administration of the claims and a legal entitlement for the affected households and companies to compensations is missing.

Moreover, public losses (e.g. loss of municipal infrastructure, schools, etc.) were summed up in order to compare them with the costs of emergency. Finally, the share of emergency costs can be calculated on a municipal basis. The mean of emergency costs is about 40.4 per cent of the total direct

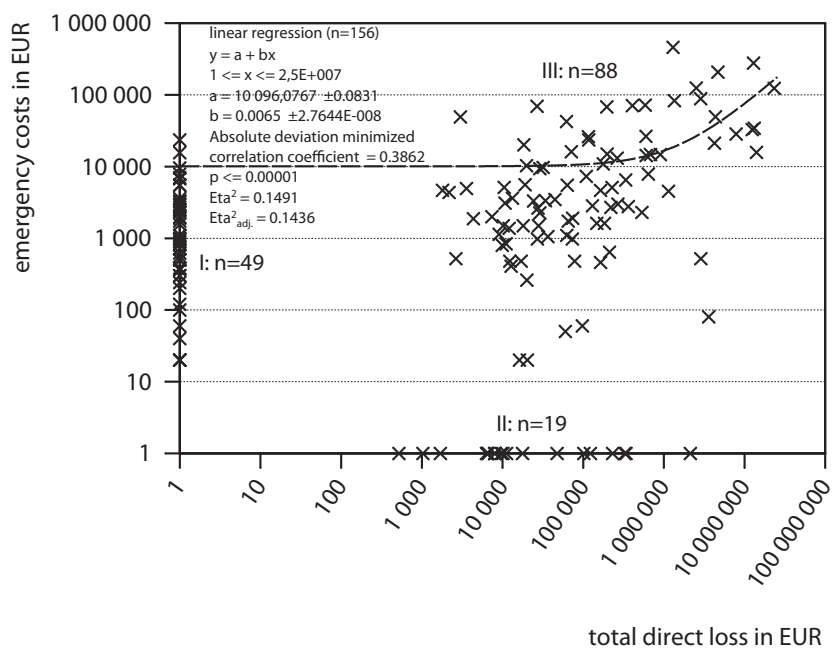

Fig. 7. Logarithmic scatterplot of the total direct losses and the costs of emergency per municipality.

losses (median 9.8, Fig. 6). These results serve as an approximation for economic emergency costs compared with the total direct losses. On average, the costs of emergency per municipality were about EUR 15390 (median EUR 1895).

A breakdown of the costs of emergency across municipalities showed that in more than 50 per cent of the municipalities emergency costs were less than 10 per cent of the total direct losses, but also that these costs were often the only listed cost category during the 2005 floods in Tyrol. More than 35 per cent of the municipalities had to face emergency costs amounting to more than 100 per cent of the total direct losses (Fig. 6).

By simply plotting the costs of emergency (using service hours and hourly wage) and the total direct losses per municipality logarithmically, we find a high data variance with outliers and, in essence, three groups of data (Fig. 7). Group I represents those municipalities without any direct loss, but with incurred emergency costs for a successful defence. Group II comprises those municipalities with no incurred emergency costs, but with direct losses. Group III plots the relation of direct losses to emergency costs and represents the highest fraction of municipalities.

Estimating a linear regression (absolute deviation minimised) on these data (Fig. 7), we observe relatively stable emergency costs up to approx. EUR 1 million of direct losses. Above that level the emergency costs rise disproportionately. Despite the low accuracy of this linear regression, the emergency costs correlate moderately with the total direct losses. This is an important hint for a better understanding of the relation of total direct costs to the costs of emergency and could be a basis for damage functions also estimating emergency expenses. 
The variability of data and results is high and so are the uncertainties. For comparability to fixed costs of mitigation, the costs of emergency in relation to municipality area and inhabitants are of importance. Apart from 18 municipalities without any emergency costs, the average costs per inhabitant were computed to EUR 10.1 (median EUR 1.1). The average costs for emergency per area in $\mathrm{km}^{2}$ are EUR 1747 (median EUR 61.3). To conclude, Alpine regions and the municipalities are highly variable in terms of inhabitants, total areas and estimated costs for emergency. This hampers exact quantification, but using average or median values could be an approach for dealing with the high variability of such costs.

\section{Conclusions and recommendations for public risk and disaster management}

The cost of public safety, particularly the cost of mitigation and emergency, is an essential component in analysing the costs of past catastrophic events, but also in determining them as costs (costs for mitigation) and benefits (costs for emergency) in cost efficiency assessments for structural and non-structural mitigation. Missing consistency in terminology and appropriate approaches as well as a lack of empirical data hamper an estimate of these costs, although their analysis would improve estimates of these costs and improve investigations of cost-efficiency of measures.

\subsection{Costs of mitigation}

About 44 to 216 EUR per year and capita and about 6300 to 78500 EUR per year and $\mathrm{km}^{2}$ were spent on hazard mitigation in the Autonomous Province of South Tyrol, Italy, the Federal State of Tyrol, Austria, Switzerland and the Free State of Bavaria, Germany, in the assessed year (see Sect. 3). This result can serve as an approximation for mitigation costs for the public risk and disaster management of Alpine hazards, although we analysed the costs of one reference year only. The analysis was quite labour-intensive as multiple administrative bodies were involved at diverse levels. Based on the findings, recommendations for the public risk and natural hazard management can be given.

First of all, the establishment and harmonization of data would improve the reliable quantification of these costs. Second, to put decision making on a sound basis, we strongly suggest assessing the annual costs for mitigation regularly, comprehensively, and hazard-specifically. Based on our analysis of the annual costs of mitigation, a cost-effective review of the implemented measures could be carried out if the prevented loss was also analysed in detail.

The costs for mitigation and emergency (public safety) are not exactly quantifiable at the moment. Hence, society's need for security cannot clearly be expressed in monetary terms. With a view to supranational cooperation and harmonization, but also for benchmarking the different risk management systems implemented in the member states of the EU, a detailed analysis of both the incurred losses and costs for mitigation is desirable to establish a common basis for future risk prevention strategies.

\subsection{Costs of emergency}

At present, variable costs of emergency services are often not included in damage assessment and economic planning of mitigation measures. The effect of omitting these costs in event analyses and cost-benefit-analyses can be substantial. A comparison of costs and benefits of different hazard control options will make a huge difference to the costs of emergency services in extreme events, since the protection of valuable assets is one of the major cost drivers for emergency spending. In the assessed region (Tyrol, Austria, 2005-flood) the data vary greatly. Hence we assume that the fragmentation of the natural and socio-economic settings in mountain areas strongly influence emergency costs.

The results serve as an approximation to estimate emergency costs accruing at the fire departments, despite the high data variance at local level. The mean of approximately 10 to 12 per cent of the total direct costs in the case of inland floods (median 5 to 6, based on Penning-Rowsell and Wilson, 2006 and data provided by W. Kron, based on IKSE 2004 and other information from public agencies) and the median of about 40 per cent for Alpine floods (median 9.8) seem to be benchmarks to estimate these costs ex-ante.

We are aware that the scarcity of the observations may distort the results. Only one catastrophic event was analysed since data from other incidents were not available. Compared to pre-disaster costs of mitigation - about EUR 114 per year and capita and about EUR 11100 per year and $\mathrm{km}^{2}-$ the computed costs are very low with EUR 10 per inhabitant (median 1.1) and EUR 1747 (median 61.3) per area.

The often marginal permanent settlement area and the frequent coincidence of special process characteristics (e.g. multiple hazards in Alpine lateral valleys) are typical for these regions. These specifications appear in our study as empirically unobserved characteristics of the location and are featured with high residual variance and deserve further investigation. As quantity and quality of observed locational data increase, improved investigation will be possible into the damages and a validation of the estimated cost functions by data from municipalities currently not included in the sample.

In economic terms, the voluntarily organized fire departments are an important component of local and regional disaster management. If these forces had to be paid, the total cost of disasters would rise, dramatically so in the case of low-income municipalities. Although some basic data und research exists, applied approaches of the analysis of emergency costs are largely missing. Harmonization of data and data collection at all administrative levels and 


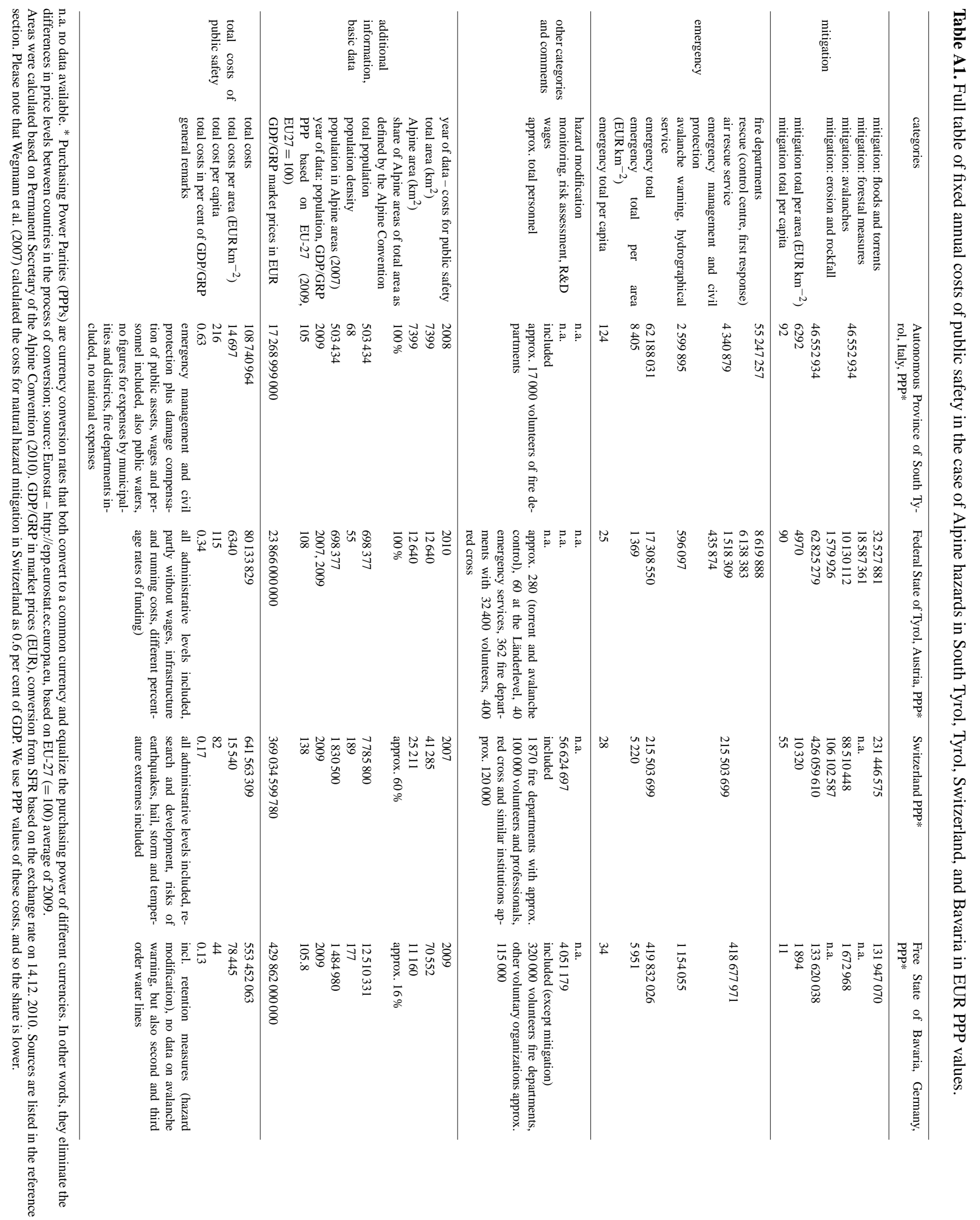


private institutions in charge of natural hazard management is needed. For single mitigation projects cost-benefit-analyses or cost-efficiency-analyses are carried out, but emergency costs are usually not assessed. Neglecting them distorts costbenefit-ratios and may result in misguided decisions. In order to improve risk management strategies, local and regional case studies and event analyses for emergency costs must be undertaken.

\section{Data sources for Table 3 (all in German):}

- Autonomous Province of South Tyrol (Italy):

- regional accounts data: www.provincia.bz.it/astat/de/volkswirtschaft/ volkswirtschaftliche-gesamtrechnung.asp, last access: 12 December 2010,

- budget 2006 to 2008: www.provinz.bz.it/ finanzen-haushalt/haushalt/landeshaushalt.asp, last access: 16 March 2011,

- population data: Südtirol in Zahlen, www.provinz.bz.it/astat/de/service/845.asp? 1\&830_action=300 \&830_image_id=229966, last access: 11 August 2011,

- number of volunteers and fire departments: Landesverband der Feuerwehren Südtirols, www.lfvbz.it, last access: 11 August 2011.

- Federal State of Tyrol (Austria)

- general data: Federal State of Tyrol (2010): Tirol Daten 2010, www.tirol.gv.at/fileadmin/ www.tirol.gv.at/themen/zahlen-und-fakten/ statistik/downloads/stat_fold10.pdf, last access: 13 October 2010,

- public budgets: Federal State of Tyrol (2010): Landesbudget 2010, www.tirol.gv. at/themen/zahlen-und-fakten/landesbudget/ landesbudget-2010/landesvoranschlag-2010/, last access: 11 August 2011.

- personal communication by the Federal Government, 2008: A. Popeller and A. Gruber

- Red Cross Tyrol: www.roteskreuz.at/tirol/ organisieren/landesrettungskommando/, last access: 11 August 2011

- Switzerland:

- population data: www.bfs.admin.ch/bfs/portal/ de/index/themen/01/01/key.html, last access: 11 August 2011,

- GDP data: www.bfs.admin.ch/bfs/portal/de/ index/themen/04/02/01/key/bip_einw.html, last access: 11 August 2011,
- fire departments: www.swissfire.ch/, last access: 11 August 2011,

- Wegmann, M., Merz, H. and Meierhans Steiner, K.: Jährliche Aufwendungen für den Schutz vor Naturgefahren in der Schweiz - Strategie Naturgefahren Schweiz, Umsetzung des Aktionsplans PLANAT 2005-2008, Bern, 2007.

- Free State of Bavaria (Germany):

- population data: Bayerisches Landesamt für Statistik und Datenverarbeitung (2009): Bevölkerungsstand Bayerns 2009, www.statistik. bayern.de/veroeffentlichungen/download/ A1100C\%20200944/A1100C\%20200944.pdf, last access: 11 August 2011,

- GRP data: Bayerisches Landesamt für Statistik und Datenverarbeitung (2010): Bruttoinlandsprodukt in Bayern, www.statistik.bayern. de/veroeffentlichungen/download/P1100C\% 20200900/P1100C\%20200900.pdf, last access: 10 December 2011,

- emergency management in Bavaria: http://www.stmi.bayern.de/sus/ katastrophenschutz/katastrophenschutzsystem/ datenundfakten/index.php, last access: 9 September 2013,

- LFU A. Rimböck, personal communication, 2011.

Acknowledgements. This research was undertaken during the project ConHaz - Costs of Natural Hazards - funded within the 7th framework programme (FP7) of the European Community (Contract 244159. http://conhaz.org) and was also supported by the Austrian Academy of Sciences (ÖAW), Institute of Interdisciplinary Mountain Research (IGF). We are also grateful to the Tyrolean fire brigade association (A. Gruber) and to several departments of the Federal State of Tyrol, who assisted us with collecting data and provided information. Moreover, we thank A. Rimböck from the Bavarian Environmental Agency for providing mitigation costs of the Free State of Bavaria (Germany) and B. Scott for improving an earlier version of the paper. We thank S. Fuchs and one anonymous referee for useful comments which helped to revise an earlier version of the paper.

Edited by: T. Glade

Reviewed by: S. Fuchs and one anonymous referee 


\section{References}

Alexander, D.: Principles of Emergency Planning and Management, Oxford, 2002.

Alpine Convention: Alpensignale 1, Innsbruck, 2010 (in German).

Altay, N., Prasad, S., and Tata, J.: A dynamic model for costing disaster mitigation policies, Disasters, 37, 357-373, 2013.

Benson, C. and Clay, E. J.: Understanding the Economic and Financial Impacts of Natural Disasters, Disaster Risk Management Series No. 4, The World Bank, Washington DC, 2004.

Boswell, M., Deyle, R., Smith, R., and Baker, E.: A Quantitative Method for Estimating Probable Public Costs of Hurricanes, Environ. Manage., 23, 359-372, 1999.

Bouwer, L. M., Poussin, J., Papyrakis, E., Daniel, V. E., Pfurtscheller, C., Thieken, A. H., and Aerts, J.: Methodology report on costs of mitigation, ConHaz report of WP4 Mitigation and Adaptation, Amsterdam., available at: http://conhaz.org/ project/cost-assessment-work-packages/wp1-8-final-reports/

CONHAZ\%20REPORT\%20WP04_2.pdf/at_download/file, last access: 20 November 2011.

Carter, W.: The disaster management cycle, in: Disaster management: A disaster manager's handbook, edited by: Carter, W., Asian Development Bank, Manila, 51-59, 1991.

Central Auditing Authority of the Federal State of Tyrol: Rechnungsabschluss 2005 des Landes Tirol, available at: www.tirol. gv.at/fileadmin/www.tirol.gv.at/landtag/landesrechnungshof/ downloads/ber_2006/e2006rechnungsabschluss05internet.pdf (last access: 12 December 2011), 2006 (in German).

Changnon, S. A.: Shifting Economic Impacts from Weather Extremes in the United States: A Result of Societal Changes, not Global Warming, Nat. Hazards, 29, 273-290, 2003.

Downton, M. W. and Pielke, R. A.: How accurate are Disaster Loss Data? The Case of U.S. Flood Damage, Nat. Hazards, 35, 211228, 2005.

EM-DAT: The OFDA/CRED International Disaster Database, available at: www.emdat.be, Université Catholique de Louvain, Brussels, Belgium, last access: 9 September 2013.

Emergency Management Australia (EMA): Emergency management in Australia - concepts and Principles, Australian emergency manual series, manual number 1, Dickson, 2004.

Federal Fire Brigade Association of the Tyrol (Landesfeuerwehrverband Tirol): Tarifordnung, available at: www.lfv-tirol.at/dokumente/doc_details/41-tarifordnung.html (last access 21 March 2012), Innsbruck, 2010 (in German).

Federal Ministry of Agriculture, Forestry, Environment and Water Management: Hochwasser 2005 - Ereignisdokumentation der Bundeswasserbauverwaltung, des Forsttechnischen Dienstes für Wildbach- und Lawinenverbauung und des Hydrographischen Dienstes, Vienna, 2006 (in German).

Federal Ministry of Agriculture, Forestry, Environment and Water Management: Kosten-Nutzen-Untersuchungen im Schutzwasserbau - Richtlinie, KNU gemäß $§ 3$ Abs. 2 Ziffer 3 Wasserbautenförderungsgesetz, Vienna, 2008a (in German).

Federal Ministry of Agriculture, Forestry, Environment and Water Management: Richtlinien für die Wirtschaftlichkeitsuntersuchung und Priorisierung von Maßnahmen der Wildbachund Lawinenverbauung gemäß $\S 3$ Abs. 2 Z 3 Wasserbautenförderungsgesetz 1985, Vienna, 2008b (in German).

Federal Ministry of Finance: Hochwasseropferentschädigungsund Wiederaufbau-Gesetz 2002, available at: www.bmf.gv.at/
budget/finanzbeziehungen-zu-laendern-und-gemeinden/HWG 2002.pdf?3vtkfo (last access: 10 July 2013), Vienna, 2002 (in German).

Federal Ministry of Finance: Hochwasseropferentschädigungsund Wiederaufbau-Gesetz $2005 \quad-\quad$ HWG 2005, available at: www.bmf.gv.at/budget/ finanzbeziehungen-zu-laendern-und-gemeinden/HWG_2005. pdf?3vtkfo (last access 10 July 2013), Vienna, 2005 (in German).

Federal Ministry of Finance: Katastrophenfondsgesetz 1996 - Neunter Bericht des Bundesministeriums für Finanzen, available at: www.bmf.gv.at/ budget/finanzbeziehungen-zu-laendern-und-gemeinden/ Katastrophenfondsbericht_2010-2011.pdf?3vtkfo (last access: 10 July 2013), Vienna, 2012 (in German).

Federal State of Saxony-Anhalt: Bericht Hochwasserkatastrophe, available at: www.sachsen-anhalt.de/LPSA/fileadmin/Files/ Bericht_Hochwasserkatastrophe_2002.pdf (last access 12 January 2012), Magdeburg, 2002 (in German).

Federal State of Tyrol: Landes-Feuerwehrgesetz 2001, Innsbruck, 2001 (in German).

Federal State of Tyrol: Hydrologische Übersicht August 2005, available at: www.tirol.gv.at/uploads/media/hueb0805.pdf, last access: 5 June 2009, Innsbruck, 2005 (in German).

Federal State of Tyrol: Landesbudget 2010, available at: http://www.tirol.gv.at/statistik-budget/landesbudget/ landesbudget-2010/landesvoranschlag-2010/, last access: 30 September 2013, 2010.

Free State of Saxony: Bericht der Unabhängigen Kommission der Sächsischen Staatsregierung - Flutkatastrophe 2002, available at: www.schlaudi.de/hw/Kirchbachbericht.pdf (last access: 12 January 2011), Dresden, 2002 (in German).

Fuchs, S.: Susceptibility versus resilience to mountain hazards in Austria - paradigms of vulnerability revisited, Nat. Hazards Earth Syst. Sci., 9, 337-352, doi:10.5194/nhess-9-337-2009, 2009.

Fuchs, S. and McAlpin, M. C.: The net benefit of public expenditures on avalanche defence structures in the municipality of Davos, Switzerland, Nat. Hazards Earth Syst. Sci., 5, 319-330, doi:10.5194/nhess-5-319-2005, 2005.

Fuchs, S., Thöni, M., McAlpin, M. C., Gruber, U., and Bründl, M.: Avalanche hazard mitigation strategies assessed by cost effectiveness analyses and cost benefit analyses - evidence from Davos, Switzerland, Nat. Hazards 41, 113-129, 2007.

Ganderton, P.: Benefit-Cost Analysis of disaster mitigation: Application as a policy and decision-making tool, Mitigation Adapt. Strat. Global Change, 10, 445-465, 2005.

Grêt-Regamey, A., Walz, A., and Bebi, P.: Valuing ecosystem services for sustainable landscape planning in alpine regions, Mountain Res. Develop., 28, 156-165, 2008.

Gruber, M.: Alternative solutions for public and private catastrophe funding in Austria, Nat. Hazards Earth Syst. Sci., 8, 603-616, doi:10.5194/nhess-8-603-2008, 2008.

Guzzetti, F., Stark, C. P., and Salvati, P.: Evaluation of Flood and Landslide risk to the Population of Italy. Environ. Manage., 36, 15-36, 2005.

Hilker, N., Badoux, A., and Hegg, C.: The Swiss flood and landslide damage database 1972-2007, Nat. Hazards Earth Syst. Sci., 9, 913-925, doi:10.5194/nhess-9-913-2009, 2009. 
Holub, M. and Fuchs, S.: Mitigating mountain hazards in Austria - legislation, risk transfer, and awareness building, Nat. Hazards Earth Syst. Sci., 9, 523-537, doi:10.5194/nhess-9-5232009, 2009.

International Commission for the Protection of the Elbe (IKSE) 2004: Dokumentation des Hochwassers vom August 2002 im Einzugsgebiet der Elbe, Magdeburg, 2004 (in German).

Joy, C. S.: The cost of flood damage in Nyngan, Climatic Change, 25, 335-351, 1993.

Kienholz, H., Krummenacher, B., Kipfer, A., and Perret, S.: Aspects of integral risk management in practice - considerations with respect to mountain hazards in Switzerland, Österreichische Wasser- und Abfallwirtschaft, 56, 43-50, 2004.

Meyer, V., Becker, N., Markantonis, V., Schwarze, R., van den Bergh, J. C. J. M., Bouwer, L. M., Bubeck, P., Ciavola, P., Genovese, E., Green, C., Hallegatte, S., Kreibich, H., Lequeux, Q., Logar, I., Papyrakis, E., Pfurtscheller, C., Poussin, J., Przyluski, V., Thieken, A. H., and Viavattene, C.: Review article: Assessing the costs of natural hazards - state of the art and knowledge gaps, Nat. Hazards Earth Syst. Sci., 13, 1351-1373, doi:10.5194/nhess-13-1351-2013, 2013.

Oberndorfer, S., Fuchs, S., Rickenmann, D., and Andrecs, P.: Vulnerabilitätsanalyse und monetäre Schadensbewertung von Wildbachereignissen in Österreich, BfW Berichte, Bundesforschungs- und Ausbildungszentrum für Wald, Naturgefahren und Landschaft (BfW), Wien, 55 pp., 2007.

Olschewski, R.: How to value protection from natural hazards - a step-by-step discrete choice approach, Nat. Hazards Earth Syst. Sci., 13, 913-922, doi:10.5194/nhess-13-913-2013, 2013.

Olschewski, R., Bebi, P., Teich, M., Wissen Hayek, U., and GrêtRegamey, A.: Avalanche protection by forests - A choice experiment in the Swiss Alps, Forest Policy Econom., 15, 108-113, 2012.

Parker, D. J., Green, C. H., and Thompson, P. M.: Urban Flood Protection Benefits: a project appraisal guide, Gower Technical Press ("Red Manual"), Aldershot, Hants, 1987.

Penning-Rowsell, E. and Wilson, T.: Gauging the impact of natural hazards: the pattern and cost of emergency response during flood events, Trans. Inst. Br. Geogr., NS 31, 99-115, 2006.

Penning-Rowsell, E., Johnson, C., Tunstall, S., Tapsell, S., Morris, J., Chatterton, J., and Green, C.: The benefits of Flood and Coastal risk Management: A Manual of Assessment Techniques, Flood Hazard Research Centre, Middlesex University, 2005a.

Penning-Rowsell, E., Johnson, C., Tunstall, S., Tapsell, S., Morris, J., Chatterton, J., and Green, C.: The benefits of Flood and Coastal risk Management: A Handbook of Assessment Techniques, Flood Hazard Research Centre, Middlesex University, 2005 b.
Pfurtscheller, C. and Thieken, A. H.: The costs of Natural hazards in alpine environments - current practice, end-user needs and recommendations, in: Proceedings of the 12th Congress INTERPRAVENT, edited by: Koboltschnig, G., Hübl, J., and Braun, J., 2, 1045-1054, Grenoble, 2012.

Pfurtscheller, C., Lochner, B., and Thieken, A. H.: Costs of alpine Hazards, Final report of the workpackage alpine Hazards, project ConHaz, available at: http://conhaz.org/ project/cost-assessment-work-packages/wp1-8-final-reports/ CONHAZ\%20REPORT\%20WP08_1.pdf/at_download/file (last access: 27 December 2011), Innsbruck, 2011.

PLANAT (National Platform for Natural Hazards): Strategie Naturgefahren Schweiz, Synthesebericht, Biel, 2004 (in German).

Prettenthaler, F. and Vetters, N.: Finanzielle Bewältigung von Naturgefahren: Vorschläge zur Reform des Österreichischen Modells, InTeReg Working Paper Nr. 21, 2005 (in German).

Raschky, P. and Weck-Hannemann, H.: Vor- oder Nachsorge? Ökonomische Perspektiven, in: Naturrisiken und Sozialkatastrophen, edited by: Felgentreff, C. and Glade, T., Berlin, Heidelberg, 270-279, 2008 (in German).

Republik Österreich: Katastrophenfondsgesetz 1996, BGBl 201/1996, 1996.

Rudolf-Miklau, F.: Naturgefahren-Management in Österreich, Vienna, 2009 (in German).

SAFECOAST: Coastal Flood Risk and Trends for the Future in the North Sea Region, Synthesis report, Safecoast project team, The Hague, 2008.

Skoufias, E.: Economic Crises and Natural Disasters: Coping Strategies and Policy Implications, World Development, 31, 1087-1102, doi:10.1016/S0305-750X(03)00069-X, 2003.

The World Bank and the United Nations (Eds.): Natural Hazards, UnNatural Disasters: The Economics of Effective Prevention, Washington DC, 2010.

Thieken, A. H., Kreibich, H., Müller, M., and Merz, B.: Coping with floods: preparedness, response and recovery of flood-affected residents in Germany in 2002, Hydrol. Sci. J., 52, 1016-1037, 2007.

Vetters, N. and Prettenthaler, F.: Extreme Wetterereignisse: Nationale Risikotransfersysteme im Vergleich, InTeReg Working Paper Nr. 17-2004, Graz, 2004 (in German).

Wegmann, M., Merz, H., and Meierhans Steiner, K.: Jährliche Aufwendungen für den Schutz vor Naturgefahren in der Schweiz - Strategie Naturgefahren Schweiz, Umsetzung des Aktionsplans PLANAT 2005-2008, Bern, 2007 (in German).

Whitehead, J. C.: One million dollars per mile? The opportunity costs of Hurricane evacuation, Ocean Coast. Manage., 46, 10691083, 2003.

Zeckhauser, R.: The economics of catastrophes, J. Risk Uncertain., 12, 113-140, 1996.

Zhai, G. and Ikeda, S.: Flood risk acceptability and economic value of evacuation, Risk Anal., 26, 683-694, 2006. 